\title{
Sediment Characteristics over Asymmetrical Tidal Sand Waves in the Dutch North Sea
}

\author{
Chiu Hwa Cheng ${ }^{1, * \mathbb{C}}$, Karline Soetaert ${ }^{1, *}$ and Bas Wijnand Borsje ${ }^{2}$ \\ 1 Department of Estuarine and Delta Systems (EDS), NIOZ Royal Netherlands Institute for Sea Research, and \\ Utrecht University, Korringaweg 7, 4401NT Yerseke, The Netherlands \\ 2 Water Engineering and Management, University of Twente, PO Box 217, 7500AE Enschede, The Netherlands; \\ b.w.borsje@utwente.nl \\ * Correspondence: chiu.cheng@nioz.nl (C.H.C.); karline.soetaert@nioz.nl (K.S.)
}

Received: 15 April 2020; Accepted: 29 May 2020; Published: 4 June 2020

check for updates

\begin{abstract}
The behavior of asymmetrical bedforms, which include many tidal sand waves, is challenging to understand. They are of particular interest since they are mostly located within areas prone to offshore engineering activities. Most experimental investigations regarding asymmetrical bedforms consider the riverine environment, are limited to a single sand wave or a few scattered ones, and focus only on differences between crest and trough. Hardly any information is available on sediment compositional changes along asymmetrical tidal sand waves, despite their abundance offshore. An asymmetrical sand wave field located off the coast of Texel Island in the North Sea was studied in June and October 2017. A total of 102 sediment samples were collected over two seasons along a single transect that covered five complete sand waves to measure the grain size composition, organic carbon concentration, chlorophyll-a (chl-a) concentration, and sediment permeability. We found significant variations in these sediment parameters between the sand wave trough, crest, and gentle and steep slopes, including a difference in permeability of more than 2-fold, as well as a difference in median grain size exceeding $65 \mu \mathrm{m}$. Based on these characteristics, a sand wave can be divided into two discrete halves: gentle slope + crest and steep slope + trough. Our results indicate a distinct sediment-sorting process along the Texel sand waves, with a significant difference between the two halves of each sand wave. These data could serve as input for process-based modeling of the link between sediment-sorting processes and seabed morphodynamics, necessary to design offshore engineering projects.
\end{abstract}

Keywords: seabed morphology; permeability; asymmetrical sand waves; North Sea; sediment characteristics; sandy shelf seas; biogeochemistry

\section{Introduction}

Tidal sand waves are dynamic rhythmic bedforms, often found in tide-dominated, sandy, shallow coastal regions such as the North Sea, but also in many other environments such as straits and tidal inlets around the world [1-4]. They typically range from 100 to $1000 \mathrm{~m}$ in wavelength (distance from crest to crest) and have heights up to $5 \mathrm{~m} \mathrm{[1,5-7].} \mathrm{However,} \mathrm{giant,} \mathrm{10-m} \mathrm{high} \mathrm{sand} \mathrm{waves} \mathrm{have} \mathrm{also}$ been observed in other locations outside the North Sea [8-12]. One prominent feature of sand waves is their ability to migrate as a result of the residual current or tide asymmetry [13-15]. This movement, which involves up to tens of meters per year, can pose potential hazards to navigation and expose pipelines or buried cables [16]. Offshore engineering activities, such as sand mining, the disposal of dredged material, windfarm construction, shipping, and pipeline and cable installations, are projected to increase in the future. Thus, sand wave mobility is especially problematic for coastal management and calls for a solid understanding of the complete sand wave dynamics [17-20]. A multitude of studies 
have utilized models to accurately predict sand wave occurrence and movement $[1,2,4,15,18,21-26]$. More recently, model studies have focused on the development of asymmetrical sand waves [15,27]. However, as knowledge on the sediment characteristics is limited, these state-of-the-art models do not account for spatial variability in sediment composition (e.g., grain size and roughness) yet.

Bottom roughness and topography are important factors contributing to morphological pattern development [25]. Bedforms such as sand waves emerge because of tidal and wave energy dissipation, which causes instability in the sandy seabed. A balance is established between the steady stream transport from the bottom perturbation interacting with the oscillating tidal current, and the force of gravity dragging sediment downslope. Sand waves consequently grow from the resulting net sediment transport, which converges from troughs to the crests $[3,26,28-30]$. Sediment composition is directly linked to bottom roughness and thus also affects seabed disturbance rates $[23,26,30-33]$ and sand wave emergence and growth. Furthermore, local hydrodynamic conditions often give rise to differential grain-sorting phenomena that can significantly affect the spatial and temporal development of bottom morphology [34-38] and result in sand waves developing either symmetrical or asymmetrical shapes. The asymmetry (A) is measured by subtracting the distance from the crest to the trough of a gentle slope or steep slope $\left(\mathrm{L}_{1}\right.$ and $\mathrm{L}_{2}$, respectively), divided by the total length of the sand wave $(\mathrm{L})$; this shows how similar or different the two halves of a given sand wave are (Figure 1). At present there is little information on asymmetrical bedforms due to the difficulties of sampling sediment at the required fine-scale level in the field [39-43]. The few field studies available on sand waves have mostly observed coarser sediments on crests compared to troughs, but did not consistently study the composition of slopes. Also, the focus has been on grain size rather than on related components such as biogeochemical compounds [3,5,21,34,44-49].

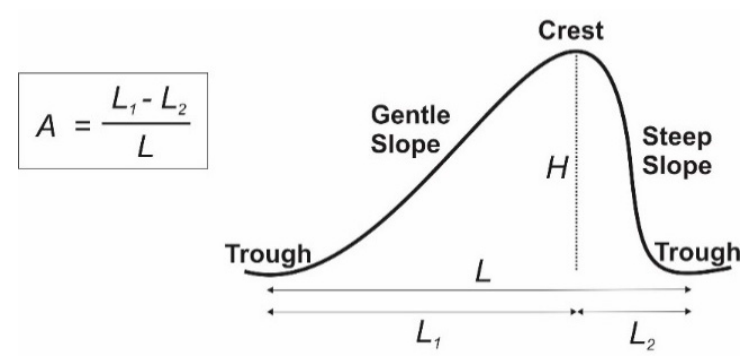

Figure 1. Schematic of an asymmetrical sand wave, with the equation for calculating the level of asymmetry $(A) . H$ represents the sand wave height and, similar to the length, is in meters. $A$ is a dimensionless value.

In this study, we sampled multiple asymmetrical sand waves in one specific location over two seasons and measured the grain size composition, the organic carbon and chlorophyll-a (chl-a) concentration, and the sediment permeability. Organic carbon and chl-a are important biogeochemical compounds because they support a wide range of metabolic and chemical activities within marine sediments, and are a food source for microbial and benthic organisms [50,51]. While chl-a is a useful measure of the readily consumed (e.g., labile) fraction of organic matter [52-56], organic carbon comprises a mix of fractions, including the more refractory compounds. Sediment permeability is increasingly recognized as an important parameter driving biogeochemical and small-scale water transport processes, especially in the upper layers of sandy sediment and around small bedforms and protrusions [57]. Particularly in sand, it is an important parameter that determines the transport of solutes and fine particles in the sediment [58-60]. Sediment permeability is closely related to the sediment grain size and the associated biogeochemical compounds within the finer fractions [61].

The aim of this study is to capture consistent, small-scale variations in sediment characteristics in a field of asymmetrical sand waves. We test whether sediment parameters differ between different sand waves, between positions within a sand wave, and between the seasons. 


\section{Materials and Methods}

\subsection{Sand Wave Symmetry and Morphological Units}

Recent data have shown that sand waves are widely distributed throughout the North Sea and are asymmetrical in shape [43]. A re-analysis of these data $[43,62]$ shows the mean asymmetry in the North Sea to be around 0.3, with asymmetry increasing towards the coast and northwards within the Dutch North Sea (Figure 2D). The level of asymmetry of sand waves is defined as the difference between the length of the gentle slope (gradual, longer side, $\mathrm{L}_{1}$ ) and the length of the steep slope (steeper, shorter side, $\mathrm{L}_{2}$ ), divided by the total length of the given sand wave (i.e., 0 is fully symmetrical, 1 is fully asymmetrical; Figure 1). We utilized the same approach for calculating the asymmetry of the Texel sand waves.
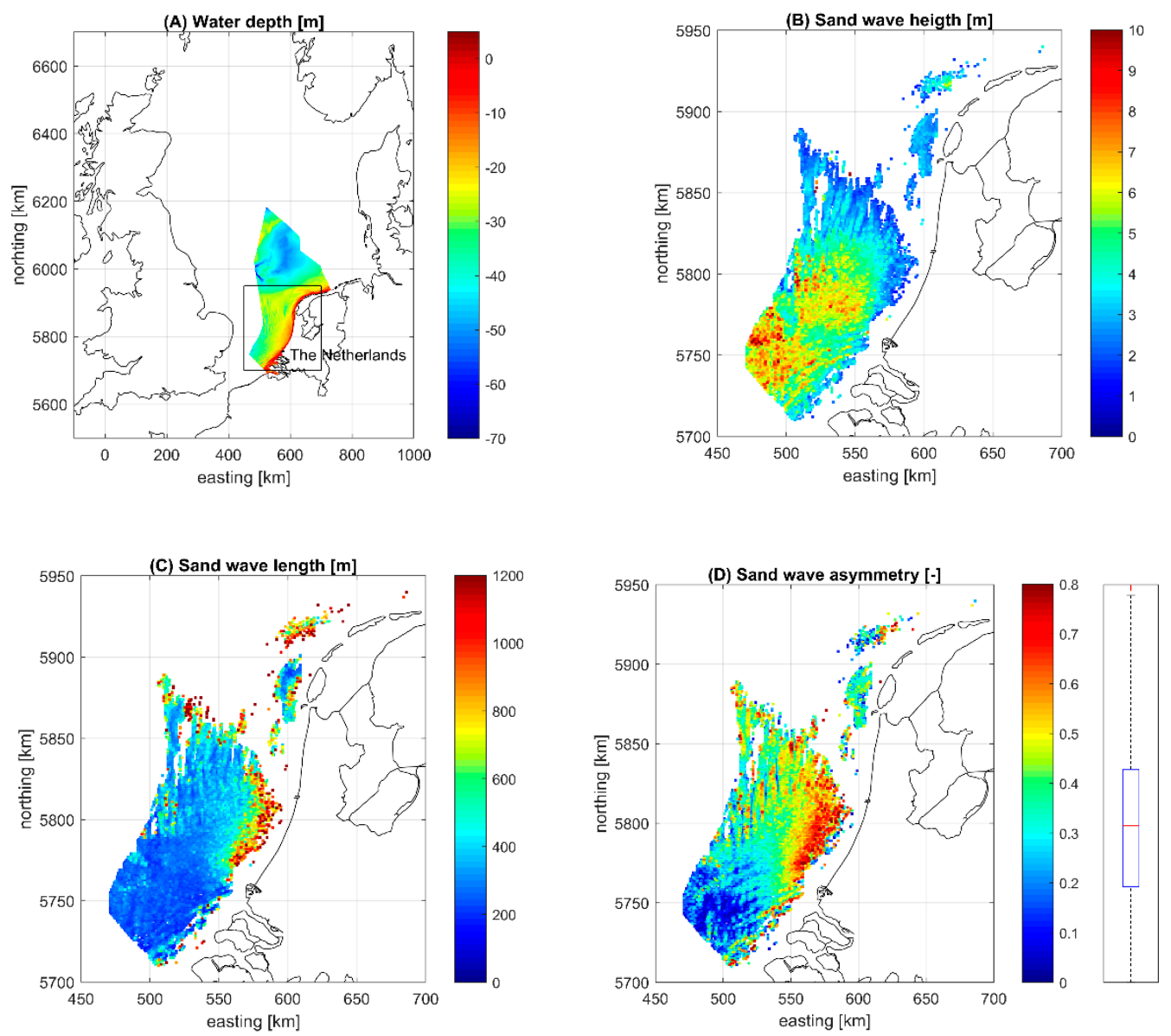

Figure 2. (A) Map of the North Sea, with the bathymetry information included for the Dutch region Maps showing the height (B) and the length (C) of the sand waves in the Dutch region. (D) Map showing sand wave distribution throughout the Dutch North Sea, as well as the level of sand wave asymmetry. The boxplot on the right shows the distribution of all the measured sand waves by their shape, with extreme examples ranging from 0 to almost 0.8 (outliers excluded). The most asymmetric sand waves are found near to the coast and towards the north. The data were extracted from a study on the environmental properties of sand waves, and aggregated per square kilometer $[43,62]$

\subsection{Study Site}

Two field campaigns to a sand wave field located in the Dutch North Sea, approximately $22 \mathrm{~km}$ offshore of Texel, were undertaken onboard the research vessel, NIOZ RV Pelagia, in June and October 2017 (Figure 3A). The particular sampling site was chosen as the mean asymmetry of these sand waves fall within the mean asymmetry value of all sand waves found in the Dutch North Sea (Figure 2D). 
Based on the equation from Figure 1, our sand waves had an asymmetry value ranging from 0.29 to 0.38. In addition, as there are shipping lanes located close to the study site, the area is subject to low levels of fishing activity [27]. This greatly reduces the occurrence of activities such as trawling, which can disturb the seabed morphology and other biogeochemical processes [63]. The sand waves extend for another 1-1.5 $\mathrm{km}$ to the north and west of our sampling area.

\subsection{Multibeam Data Collection and Selection of Sampling Locations}

The sampling area $(\sim 1 \mathrm{~km} \times 3.5 \mathrm{~km})$ was mapped with a Kongsberg EM302 Swath Multibeam echo sounder (MBES) immediately prior to each sampling operation ( $\left.53^{\circ} 11.241^{\prime} ; \mathrm{E} 4^{\circ} 28.628^{\prime}\right)$. The data from the MBES were processed with the software Fledermaus at 1-m grid resolution, with an estimated accuracy of greater than $0.6 \%$ of the depth (values supplied by manufacturer). The data contained spikes (noise) and lines that were parallel to the navigation direction due to errors in the speed of sound or from the bottom depths not being corrected for the tidal height. The data were processed with CUBE (Combined Uncertainty Bathymetric Estimator), which estimates the most probable position of the bottom. The spikes in the data had to be manually removed. The resulting bathymetric data were converted to a raster using R 3.4.4. [64], with the function rasterFromXYZ from the raster package (R. J. Hijmans, Davis, United States) [65].

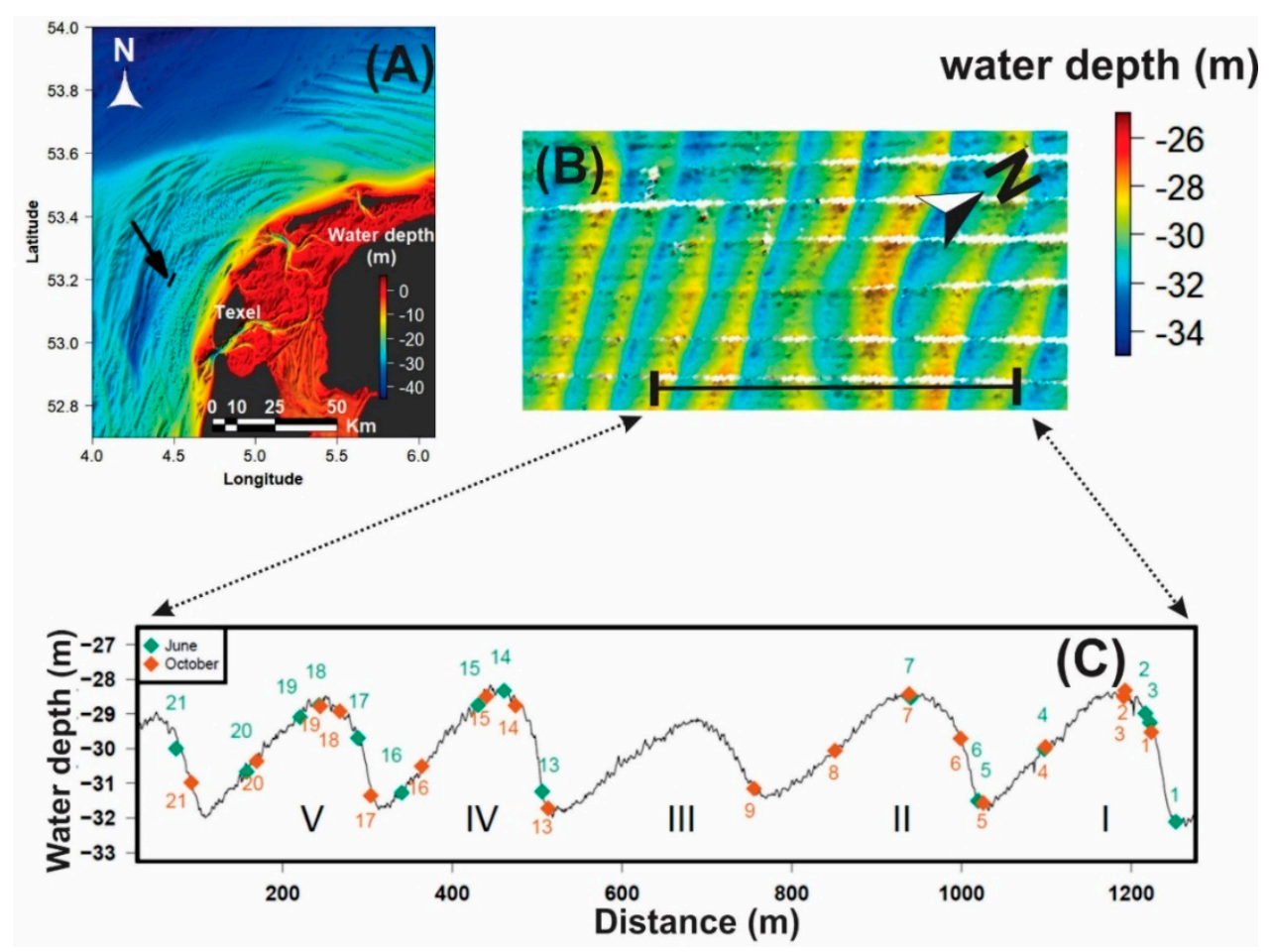

Figure 3. (A) Map showing the study location, offshore of Texel [66]. (B) Subset of the mapped area. (C) The profile was created using the processed and gridded geophysical data collected with a MBES from June, and shows a cross section of our sampling transect, with stations from both seasons plotted together.

During the MBES mapping in June, the sailing speed of the vessel was approximately $5 \pm 1$ knots. The temperature and salinity averaged $14.6 \pm 0.8^{\circ} \mathrm{C}$ and $35.2 \pm 0.02 \mathrm{ppt}$. Wind speed averaged $1.7 \pm$ $0.7 \mathrm{~m} \mathrm{~s}^{-1}$. In October, the sailing speed was approximately $2.2 \pm 1.7 \mathrm{knots}$, while the temperature and salinity averaged $15.3 \pm 1.9^{\circ} \mathrm{C}$ and $34.9 \pm 0.02 \mathrm{ppt}$. Wind speed averaged $2.8 \pm 0.9 \mathrm{~m} \mathrm{~s}^{-1}$. For additional information about the weather conditions immediately preceding and during the campaigns, including for each type of sampling, please see Figure S1. The RV Pelagia does not have a tidal correction 
mechanism or a DP (dynamic positioning system), but is equipped with a GNSS (Global Navigation Satellite System) positioning system.

\subsection{Sediment Sampling}

All samples were collected along a single transect line $(\sim 1100 \mathrm{~m})$ covering five sand waves (Figure 3C). Given the time limitations of the sampling, we positioned our stations only along the four highest sand waves (I, II, IV, and IV). The middle sand wave (III) was excluded from sampling because it was shorter than the adjacent sand waves, and we wanted to measure sand waves exhibiting the steepest gradients possible. The first campaign included 16 stations (1-7 on sand waves I and II and 13-21 on sand waves IV-V). Sediment was collected using the NIOZ multicorer (Oktopus model), equipped with eight $10 \mathrm{~cm}$ diameter cores, each $61 \mathrm{~cm}$ in length. The multicorer is neither a piston corer nor a vibracorer, so no additional mechanical forces are involved in the sediment sampling. From each of these cores, subsamples were taken by pushing a single $3.5 \mathrm{~cm}$ diameter core into the multicore sediment core, as close to the center as possible. Three subsamples were taken for grain size composition and organic carbon concentration, with another three cores subsampled for permeability. In June, the core lengths ranged from 11 to $19 \mathrm{~cm}$ in length. In October, the core lengths ranged from 4 to $17 \mathrm{~cm}$ in length. From the remaining multicore, the top $1 \mathrm{~cm}$ of sample was collected with a $60 \mathrm{~mL}$ cutoff syringe for the chl-a concentration (only one sample per station). Usually, a single deployment of the multicore was sufficient to collect all the subsamples per station. However, stations 19 and 21 were sampled with a 30-cm diameter NIOZ Box corer (K6 model) because of repeated multicorer failures due to sediment coarseness. The dimension of the box corer was approximately $32 \mathrm{~cm}$ in diameter and $55 \mathrm{~cm}$ in length. All six subsamples were taken directly from a single box core sample from the respective stations. In the second campaign, 18 stations $(1-9,13-21)$ were sampled along the same transect (extra stations: 8 and 9 on sand wave II), using the same exact sampling protocol. However, the NIOZ multi-corer was only used for stations 1, 2, 4, and 5. The remaining stations were collected with the NIOZ Box corer. Sampling was executed in relatively calm weather, with waves at most 1 to $1.5 \mathrm{~m}$ in height in June and somewhat higher in October at above $2 \mathrm{~m}$ (Figure S1).

As we expected to find a difference in the sediment parameters along the sand waves, we subdivided them into the following morphological units (MUs): crest, trough, gentle slope, and steep slope. We set the boundary of the two slopes as the regions between $0.5 \mathrm{~m}$ above the troughs and $0.5 \mathrm{~m}$ below the crests (Figure 3C).

\subsection{Sediment Samples: Grain Size Distribution, Organic Carbon, and Chl-a}

The sediment subcores were collected and kept stable in a cool location until further processing was possible. The sediment samples were stored in plastic vials and frozen at $-20^{\circ} \mathrm{C}$, weighed, freeze dried, and dry weighed; porosity was measured on 24 random samples. Samples were analyzed for grain size composition using the Malvern Mastersizer 2000 particle size analyzer (Malvern, (WM), United Kingdom) through laser diffraction [67], which measured the volume percentages of five sediment fractions: coarse sand $(500-1000 \mu \mathrm{m})$, medium sand $(250-500 \mu \mathrm{m})$, fine sand $(125-250 \mu \mathrm{m})$, very fine sand $(62.5-125 \mu \mathrm{m})$, and silt $(\leq 63 \mu \mathrm{m})$. Together, these five fractions total $100 \%$ for each sample. The median grain size (D50) was calculated from this information.

Additional sediment samples were analyzed for the total organic carbon concentration. Approximately $50 \mathrm{mg}$ from each sample was added to silver capsules and acidified with several additions of $\mathrm{HCl}$ to remove the carbonate content. The samples were then measured on a Flash2000 organic elemental analyzer (Bath, (SW), United Kingdom) [68].

The chl-a sediment samples were immediately stored in a $-80^{\circ} \mathrm{C}$ freezer upon collection, and later freeze-dried overnight back in the lab under dark conditions at $-60^{\circ} \mathrm{C}$. The samples were then extracted with $90 \%$ acetone and measured on an Analytik Jena Specord 210 spectrophotometer (Jena, (TH), Germany) with a halogen lamp [69]. 
The average length of the sediment cores was $13 \mathrm{~cm}$ in June and $9.5 \mathrm{~cm}$ in October. The results presented here are averages of the entire individual sediment cores.

\subsection{Sediment Permeability}

Sediment permeability was measured using a constant head permeameter [70,71]. The setup measures the hydraulic conductivity of sediment cores, which is used to calculate permeability as a function of the following equation:

$$
k=\frac{K \times u}{d \times g}
$$

where $k$ is the permeability $\left(\mathrm{m}^{2}\right), \mu$ is the water viscosity $\left(\mathrm{Pa}^{*} \mathrm{~s}\right)$, calculated from the temperature and salinity, $d$ is the water density $\left(\mathrm{g} \mathrm{cm}^{-3}\right), g$ is the gravitational acceleration $\left(9.81 \mathrm{~m} \mathrm{~s}^{-2}\right)$, and $K$ is the sediment hydraulic conductivity $\left(\mathrm{cm} \mathrm{s}^{-1}\right)$, calculated as follows:

$$
K=\frac{V \times L}{h \times A \times t^{\prime}}
$$

where $V$ is the water volume collected from the core $\left(\mathrm{cm}^{3}\right), L$ is the sediment length $(\mathrm{cm}), h$ is the pressure difference between the reservoir and outlet (pressure head; $\mathrm{cm}), A$ is the core cross-sectional area $\left(\mathrm{cm}^{2}\right)$, and $t$ is the time to collect $V$ (s).

\subsection{Statistical Analysis}

The effects of the MU, sand waves, and seasonality on the permeability, D50, the five sediment fractions, the organic carbon, and chl-a concentrations were tested using a three-way ANOVA (Analysis of variance) test. This test looks for any interactions and effects between three independent variables and a continuous dependent variable.

To determine the cause for any statistically significant differences, a post hoc pairwise comparison (Tukey's HSD honestly significant difference test) was run. The purpose of this is to identify where the significant differences may stem from, by comparing the means of every treatment with every other treatment to identify differences between any two means that would be greater than the expected standard error. The test compared all the MUs with one another over each sediment parameter. All statistical analyses were conducted in $\mathrm{R}$, with the lsmeans package (R. V. Lenth, Iowa City, United States) $[64,72]$.

\section{Results}

The Texel sand waves are largely asymmetric (Figure 3C), with the steep slopes oriented NNE (north-northeast), and the studied sand waves ranging from 2.8 to $3.5 \mathrm{~m}$ in height and 160 to $210 \mathrm{~m}$ in length. Out of 16 stations in June, two were located in the gentle slope, five in the crest, five in the steep slope, and four in the trough. In October, those numbers were four, seven, two, and five, respectively.

\subsection{A Note about the MBES Datasets}

The cross section shown in Figures $3 \mathrm{C}$ and $4 \mathrm{~F}$ was produced using the MBES data from June, as the MBES in October could not generate the bathymetry at equal resolution. The MBES mapping occurred over a three-day period at different times with respect to the tides in October, showing a considerable number of spikes at the interface. 

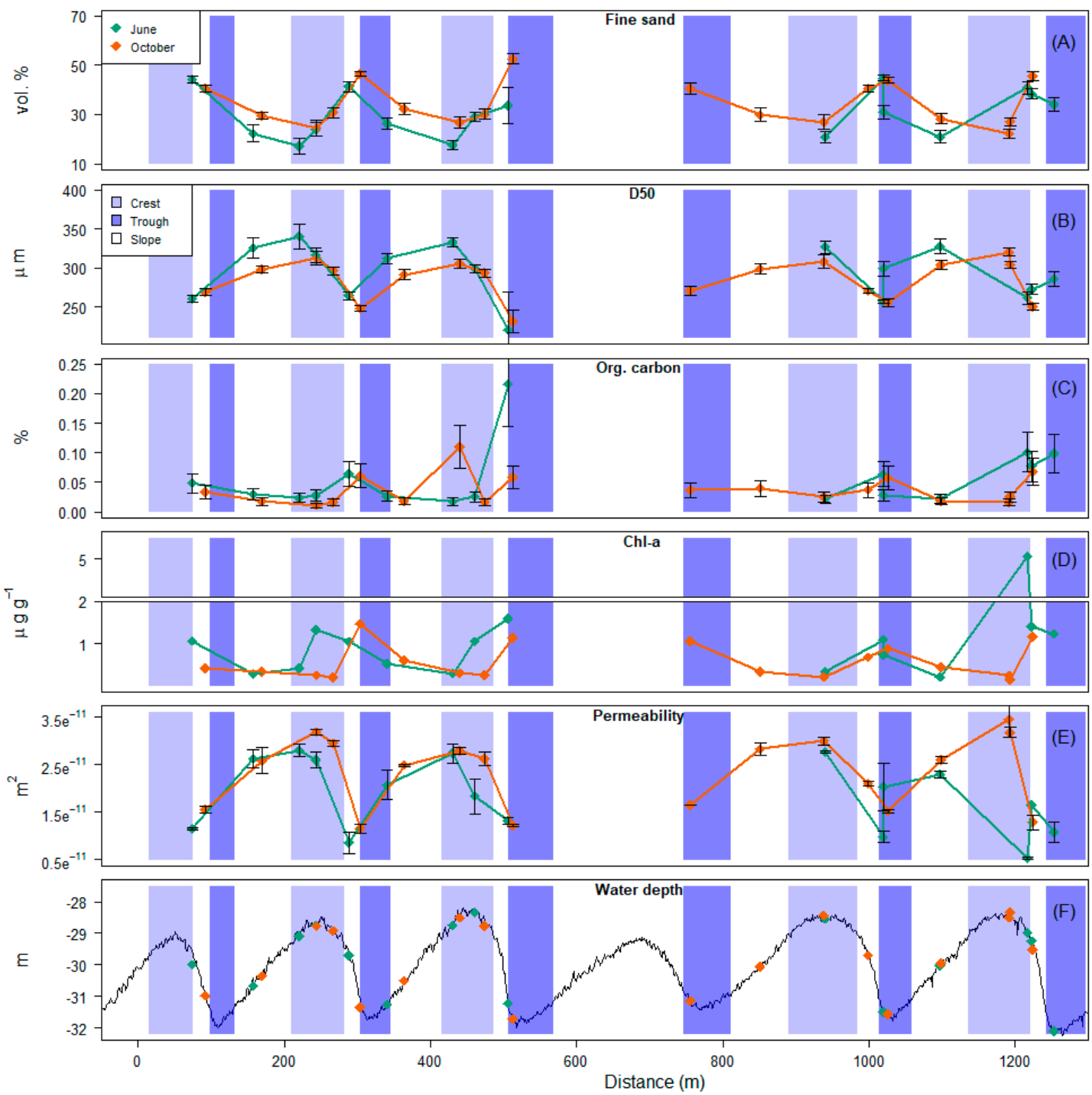

Figure 4. Selection of measured sediment parameters along the transect (mean and standard deviation) and for the two seasons. (A) Percent fine sand, (B) D50size, (C) organic carbon concentration, (D) chl-a concentration (a break in the figure is used to "rescale" the outlier), (E) sediment permeability. (F) Transect cross section, with the sampling positions from both campaigns.

\subsection{Sediment Composition, Organic Carbon, and Chl-a Content}

The percentages of fine sand, D50, and sediment permeability all show a clear pattern along the sand waves, which is consistent during both seasons (Figure 4). The sediment composition coarsens from the gentle slope side up towards the crest and decreases again down the steep slope to the trough. The finer fractions $(\leq 250 \mu \mathrm{m})$, are more abundant in the steep slope and trough locations and vice versa for the coarser fractions. A similar trend was also observed for the other sediment fractions (Table S1 and Figure S2). The silt fraction was highest in the steep slope and trough stations, as was the very fine sand fraction, but the latter was also found in very small quantities $(<0.5 \%)$ in the crest and gentle slope areas. The D50 in June averaged $288.9 \pm 34.8 \mu \mathrm{m}$, with a range of $220-340.5 \mu \mathrm{m}$, while in October the average was $284.7 \pm 25.8 \mu \mathrm{m}$, with a range of 231.1-320.5 $\mu \mathrm{m}$. The largest difference in average D50 within a sand wave was $66.4 \mu \mathrm{m}$ in June and $57.2 \mu \mathrm{m}$ in October. The average D50 was higher in June except for the gentle slope (Table S1). The largest fraction of sediment was fine sand in the steep slope and trough, while in the crest and gentle slope it was the medium sand fraction (Figure 4). Higher-resolution information on the grain size distribution is available as sediment cumulative distribution plots (Figure S3). 
The organic carbon concentration values were low overall, with the highest average falling below $0.25 \%$. Nevertheless, the organic carbon showed variations along the sand waves, following the trend of the finer fractions of sediment $(\leq 250 \mu \mathrm{m})$. The chl-a content also showed a general pattern of increase up the gentle slope towards the crest, but generally had a peak in the steep slopes, followed by the troughs with almost an 8-fold difference between the steep and gentle slope averages.

Permeability was highest on the gentle slopes in June, while in October the most permeable MU was the crests (Table S1). The permeability values were somewhat higher in October, with a range of $9.49 \times 10^{-12}-4.28 \times 10^{-11} \mathrm{~m}^{2}$ and an average of $2.35 \times 10^{-11} \mathrm{~m}^{2}$. In June, the range was $4.35 \times$ $10^{-12}-3.05 \times 10^{-11} \mathrm{~m}^{2}$ and the average was $1.88 \times 10^{-11} \mathrm{~m}^{2}$. However, all the measured samples fell within the range of the threshold that is considered permeable $\left(\geq 10^{-12}\right)$. Overall, the permeability in the crests was more than double that of the troughs, and was closely correlated to the D50. Sediment porosity averaged $0.37 \pm 0.048$ in June and $0.36 \pm 0.067$ in October, with no significant differences between the seasons and no measurable differences along the sand wave.

\subsection{Trends between the $M U s$}

Averaged over the MUs, the grain size composition and level of permeability were unevenly distributed along the sand waves, with the finest fractions completely absent from the gentle slope and crest (Figure 5). The three-way ANOVA showed that in none of the cases did the individual sand waves themselves have a significant effect on any of the measured sediment parameters (Table S2). The four MUs, when compared between each sand wave, showed no statistical difference to their counterparts $(p>0.05)$. The crest from one sand wave was not significantly different from the crests from other sand waves, and similar for the other MUs. However, all four of the MUs were significantly different from one another $(p<0.01)$ for every measured parameter, while seasonality was highly significant for permeability $(p<0.01)$, the D50, and the coarse and fine sand fractions. For the other parameters, the seasonality was not significant (Table S2). The statistical difference was larger $(p<0.01)$ when the sand waves were split into two halves (gentle slope/crest and steep slope/trough), compared to the tests that considered four individual MUs. Additional information can be found in Figure S4.

The post hoc pairwise comparison (Tukey's HSD honestly significant difference test) showed that in all cases the steep slope was not as significantly different from the trough and, likewise, the crest and gentle slope MUs were less significantly different from each other. In comparison, all of the other combinations were more significantly different. In accordance with the ANOVA results, this means that the crest and gentle slope, while still statistically significantly different from each other, are much more different to the steep slope and trough. Similarly, the trough and steep slope are less significantly different from one another than they are to the crest and the gentle slope.

\section{Discussion}

Given the scarcity of field information about sediment characteristics across asymmetrical sand waves, the aim of our field campaigns was to determine the sedimentological properties of these bedforms. Therefore, we discriminated between different MUs (gentle slope, crest, steep slope, trough) and showed that this leads to measurable changes in the sediment characteristics. On the one hand, our results are consistent with previous field studies in that the sediment is mostly coarser in crests than in the troughs [34,44-47]. However, in addition to these studies [3,5,48,73], we improved upon the sampling resolution by dividing the sand waves into smaller sections (e.g., $4 \mathrm{MUs}$ ). Whereas it was difficult to equally sample all MUs from every sand wave (Figure 3C), we successfully sampled many stations (16 in June; 18 in October) along four sand waves, and collected 102 samples in total. Bathymetric data were recorded during both campaigns, but we were not able to determine the actual migration rate of our sand waves due to the vessel's technical limitations (see Section 2.3) and also the many known sources of possible error, such as positioning, bed level noise, and depth distortions. However, previous calculations on several sand wave locations with similar orientations within the Dutch North Sea show a migration rate ranging from less than 1.0 to $8.4 \mathrm{~m} \mathrm{yr}^{-1}$, with an error of up 
to $2 \mathrm{~m}$ [74], and some of these figures may even have been overestimated [75]. Although information about the migration rate of the Texel sand waves is not presently available, it is a relevant aspect that should be taken into consideration by future studies concerning dynamic bedforms.

The difference in sediment median grain size (D50 in $\mu \mathrm{m}$ ) between crests and troughs was up to $25 \%$ of the mean and much greater than found in sand waves of comparable size and dimensions from other studies $[3,5,48]$. Moreover, the sediment coarsened from the gentle slope towards the crest, while the three finest fractions of sediment exhibited significantly higher percentages on the steep slope and trough sections (Figure 5, right panels). These results suggest that sediment sorting along the asymmetrical bedforms effectively creates a distinct gradient between the crest and trough boundary, subdividing the sand waves into two halves: the gentle slope up to the crest, and the steep slope down to the trough. Our higher-resolution sampling thus clearly demonstrates that asymmetrical sand waves are highly complex bedforms with respect to sediment granulometry, permeability, and biogeochemistry.
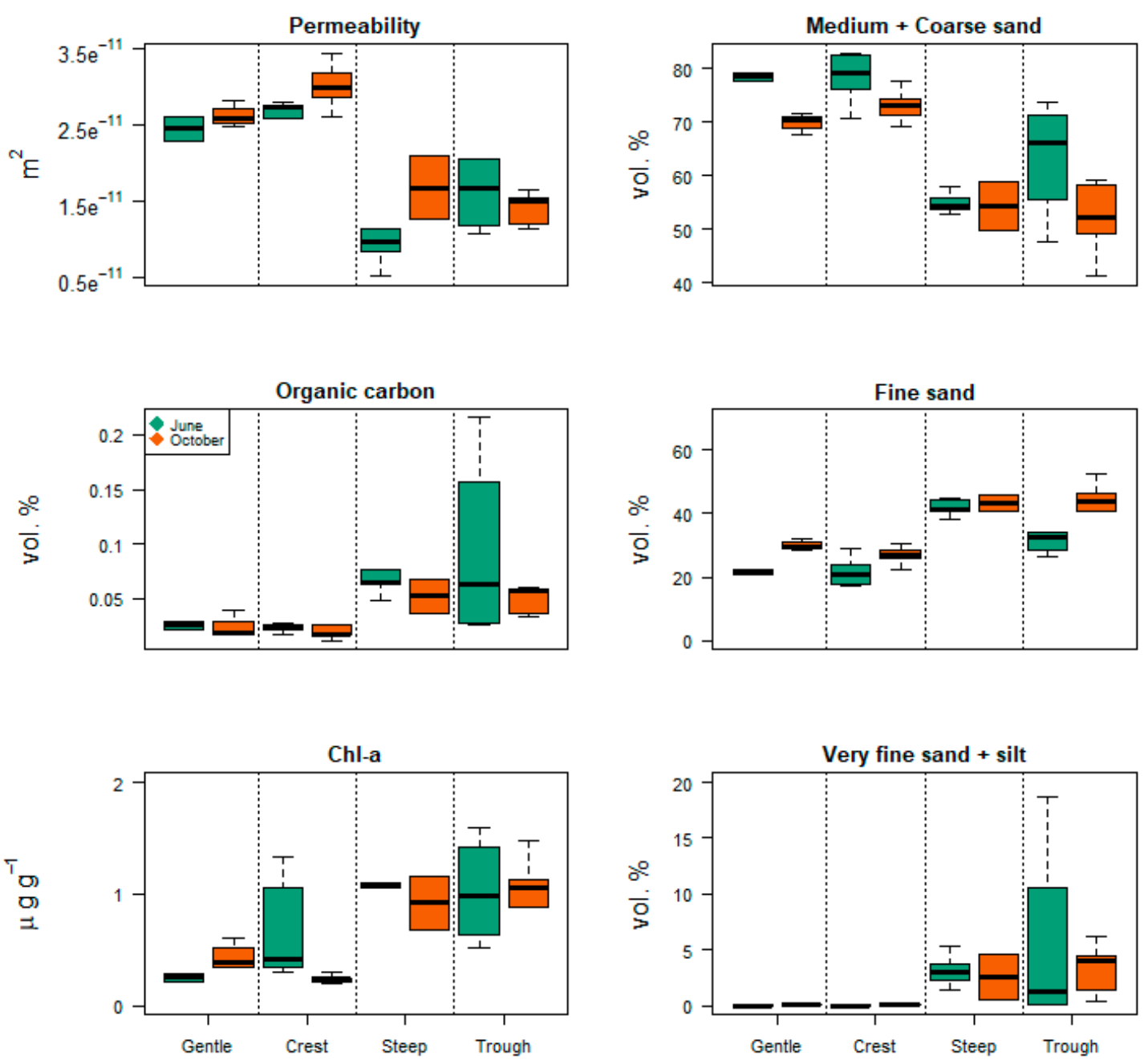

Figure 5. Comparison of selected sediment grain size parameters, organic carbon, chl-a, and permeability between June and October, averaged over the sand wave MUs. The coarse-medium fractions and the very fine sand-silt fractions were combined as these pairs followed the same trends over the MUs.

Sediment permeability generally correlates positively with increasing grain size [33]. In line with this, permeability was about twice as high on gentle slopes compared to the troughs in the summer, while in autumn the largest difference was between the crests and troughs. Permeability is a measure for the degree to which currents and waves penetrate the sediment; this has a crucial effect on the sediment 
nutrient or oxygen levels and the organic carbon concentrations. It has been shown that in sediments with a permeability of $\geq 10^{-12} \mathrm{~m}^{2}$, advective transport mechanisms become significant in regulating biogeochemical processes $[57,61,76]$. While all of our samples exceeded that threshold, the greater than two-fold difference means that solute transport could potentially occur at twice the rate in the coarsest areas of the sand wave. This also suggests that subtle biogeochemical differences might be found between the more permeable gentle slope and crest part of the sand waves, compared to the steep slope and trough.

Organic compounds are known to accumulate more in finer sediments; in particular, their concentrations are related to the mud and silt fractions [54,77-79]. In line with this, we found the chl-a and organic carbon concentrations to be significantly higher on the steep slope and troughs. Chl-a is a measure for the readily consumed (e.g., labile) fraction of organic matter, so higher concentrations can support higher overall metabolic activity in the sediment. This is consistent with the higher benthic biomass and activity found in the trough [27]. Furthermore, it is also relevant here, since benthic organisms can redistribute the upper layers of sediment, enabling the burial of fine material. A video transect study on the crest-trough comparisons showed four times more animals living on the sediment (epibenthos) and 30 times more holes (a proxy used for endobenthos) in the troughs, although the species composition could not be quantitatively determined based on this information [27]. In addition, [27] observed either highly irregular bedforms, or sometimes the complete absence of them in the troughs of the Texel sand waves. Such smaller bedforms are often superimposed on sand waves and are important as they alter the bed roughness and can slowly migrate along the gentle slope $[4,9,80]$.

Differences among MUs were clearly observed over all sand waves and during both seasons of sampling. Surprisingly, however, there were also some notable differences between June and October, although they were less pronounced than the spatial gradients. There was significant seasonal variability in some sediment fractions, sediments being coarser in June, while both the organic carbon and chl-a content were significantly higher in June. The seasonal differences observed in sediment composition could be due to extreme weather conditions (e.g., storms), which may have winnowed the sediments preceding our June campaign, while fine particles may have accumulated in the sand between the June and October field campaigns [5,81]. The higher chl-a concentration might be related to the spring phytoplankton bloom being deposited on the sediment preceding our June campaign $[53,82,83]$. Contrary to expectations, however, sediment permeability was found to be lower in June, notwithstanding the sediments being coarser. As a consequence, the relationship between permeability and D50 is ambiguous, showing a dependency on both the grain size and the season (Figure 6). This seems consistent with studies pointing to factors other than D50 that can also affect permeability, such as the grain shape, type of sediment, or sediment structure [84-86]. It is also possible that the seasonal dependency is linked to the higher concentration of organic carbon in June, as organic compounds in the silty fraction can alter the cohesiveness of the sediment $[54,77-79,87]$. Biogenic substances such as chl-a, organic matter, and biofilm compounds (e.g., extracellular polymeric substances) can increase sediment flocculation or cohesion at the microscale level and have consequences on transport processes on local or even larger scales [51,87-89]. Although this was beyond the scope of our study, other properties such as sediment structure and type should also be considered in future studies, as they could have an effect on grain size determinations $[86,90,91]$. 


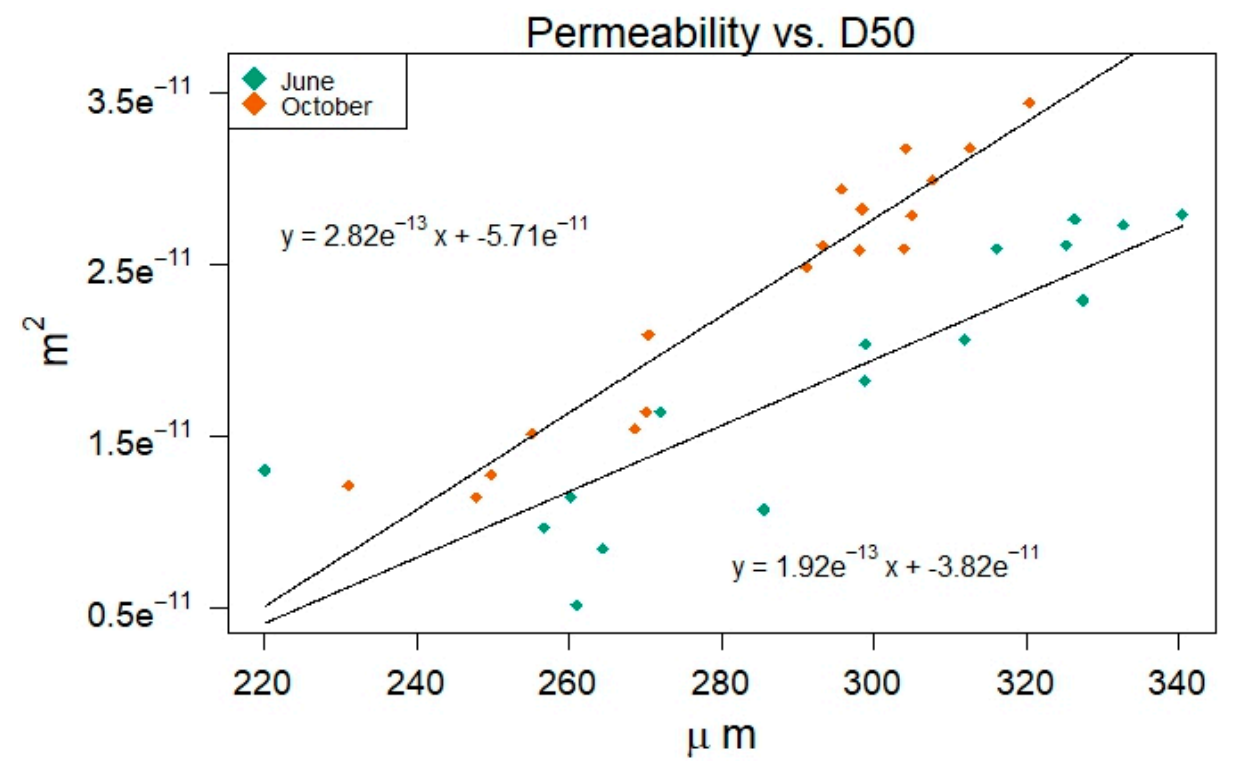

Figure 6. The relationship between permeability and the D50 in the two seasons. The individual regressions are shown.

Tidal sand waves are ubiquitous bedforms and occur over a broad range of dimensions in sandy shelf seas. Our field results demonstrate that asymmetrical sand waves exhibit significant spatiotemporal complexities in sediment sorting over small spatial scales, due in part to their irregular shape. While we found consistent spatial trends over two seasons, there is also evidence that these trends are modulated by other factors, probably of biological or biogeochemical origin.

\section{Conclusions}

The sorting of sediment along sand waves with an asymmetry value of 0.29-0.38 was studied at a sand wave field in the Dutch Continental Shelf over two seasons. By classifying the sand waves into four morphological units (gentle slope, crest, steep slope, and trough) we were able to demonstrate significant differences in the sediment grain size, organic carbon concentration, chl-a content, and permeability. The average D50 differed by more than 20\% (>60 $\mu \mathrm{m}$ difference in June and $>50 \mu \mathrm{m}$ in October), and permeability by more than two-fold between the crests and troughs, as well as between the crests and steep slopes. This was even more pronounced for the biogeochemical compounds of organic carbon and chl-a, with differences from 4- to 8-fold. Moreover, all of these patterns were observed over two seasonal campaigns. This study sheds light on the small-scale processes that couple the dynamics of sand wave morphology and sediment characteristics, and contributes information previously unavailable to help improve physical or ecosystem models to better understand these environments.

Supplementary Materials: The following are available online at http://www.mdpi.com/2077-1312/8/6/409/s1. Supplementary Figure S1: Wave height and mean wind speed during each campaign. Supplementary Figure S2: Additional grain size information. Supplementary Figure S3: Sediment cumulative distribution plots. Supplementary Figure S4: Other grain size parameters. Supplementary Table S1: Sediment results. Supplementary Table S2: Statistical results.

Author Contributions: The listed authors in this manuscript have each contributed significantly to the collection of data, analysis and interpretation of the results, and drafting of the paper. Furthermore, each author has contributed substantial time to the editing and revising of each individual section within the manuscript. The study was initiated by the first and third authors, C.H.C. and K.S., who were also fully involved in the methodology, field campaigns, and sample collection. Data analysis was primarily conducted by C.H.C., but K.S. and B.W.B. contributed as well. Discussions of the manuscript content involved all of the co-authors (C.H.C., B.W.B. and K.S.) throughout the drafting and interpretation of the contents. Each co-author also contributed to the final stages of the writing and review. All authors have read and agreed to the published version of the manuscript. 
Funding: This research was funded by the SANDBOX project, which is a part of NWO-ALW (Nederlandse Organisatie voor Wetenschappelijk Onderzoek-Aard-en Levenswetenschappen). The Royal Boskalis Westminster N.V., the Royal Netherlands Institute for Sea Research (NIOZ), and Utrecht University are acknowledged for their financial support of this project.

Acknowledgments: Many thanks to Erik Hendriks, Johan Damveld, Sarah O'Flynn, Justin Tiano, Karin van der Reijden, Leo Koop, Rob Witbaard, Pieter van Rijswijk, and Anton Tramper, who contributed to the sample collection and data contribution for this project from the cruise campaigns. We are very grateful to Texel NMF staff for their support in making both research campaigns successful, and to Henk de Haas for his help with the MBES data and other technical details. Thanks, also, to Peter van Bruegel for the analysis of the sediment samples, Natalie Steiner for helping with the statistical analyses, Jaco de Smit for the cumulative grain distribution analyses, and the many other colleagues who offered assistance along the way. The data collected for this publication can be found in the 4TU Centre for Research Data repository at the following link: 10.4121/uuid:9f6e21c5-f35b-4bca-a468-7534e04bb240. Lastly, we want to thank the reviewers for all of their input, which aided us in further improving this manuscript.

Conflicts of Interest: The authors declare no conflict of interest. The funders had no role in the design of the study; in the collection, analyses, or interpretation of data; in the writing of the manuscript, or in the decision to publish the results.

\section{References}

1. Besio, G.; Blondeaux, P.; Brocchini, M.; Hulscher, S.J.M.H.; Idier, D.; Knaapen, M.A.F.; Németh, A.A.; Roos, P.C.; Vittori, G. The morphodynamics of tidal sand waves: A model overview. Coast. Eng. 2008, 55, 657-670. [CrossRef]

2. Borsje, B.W.; Bouma, T.J.; Rabaut, M.; Herman, P.M.J.; Hulscher, S.J.M.H. Formation and erosion of biogeomorphological structures: A model study on the tube-building polychaete Lanice conchilega. Limnol. Oceanogr. 2014, 59, 1297-1309. [CrossRef]

3. Van Dijk, T.A.G.P.; Kleinhans, M.G. Processes controlling the dynamics of compound sand waves in the North Sea, Netherlands. J. Geophys. Res. Earth Surf. 2005, 110, 1-15. [CrossRef]

4. Van Santen, R.B.; de Swart, H.E.; van Dijk, T.A.G.P. Sensitivity of tidal sand wavelength to environmental parameters: A combined data analysis and modelling approach. Cont. Shelf Res. 2011, 31, 966-978. [CrossRef]

5. Baptist, M.J.; van Dalfsen, J.; Weber, A.; Passchier, S.; van Heteren, S. The distribution of macrozoobenthos in the southern North Sea in relation to meso-scale bedforms. Estuar. Coast. Shelf Sci. 2006, 68, 538-546. [CrossRef]

6. De Jong, M.F.; Baptist, M.J.; Lindeboom, H.J.; Hoekstra, P. Short-term impact of deep sand extraction and ecosystem-based landscaping on macrozoobenthos and sediment characteristics. Mar. Pollut. Bull. 2015, 97, 294-308. [CrossRef]

7. Lobo, F.J.; Hernández-Molina, F.J.; Somoza, L.; Rodero, J.; Maldonado, A.; Barnolas, A. Patterns of bottom current flow deduced from dune asymmetries over the Gulf of Cadiz shelf (southwest Spain). Mar. Geol. 2000, 164, 91-117. [CrossRef]

8. Barnard, P.L.; Hanes, D.M.; Rubin, D.M.; Kvitek, R.G. Giant sand waves at the mouth of San Francisco Bay. Eos. Trans. Am. Geophys. Union 2006, 87, 285-289. [CrossRef]

9. Hanes, D.M. The genesis of an inter-field marine sandwave and the associated anti-asymmetry migration of neighboring crests. Geophys. Res. Lett. 2012, 39, 1-7. [CrossRef]

10. Liao, H.R.; Yu, H.S. Morphology, hydrodynamics and sediment characteristics of the Changyun sand ridge offshore western Taiwan. Terr. Atmos. Ocean. Sci. 2005, 16, 621-640. [CrossRef]

11. Santoro, V.C.; Amore, E.; Cavallaro, L.; De Lauro, M. Evolution of sand waves in the Messina Strait, Italy. Ocean Dyn. 2004, 54, 392-398. [CrossRef]

12. Katoh, K.; Kume, H.; Kuroki, K.; Hasegawa, J. The Development of Sand Waves and the Maintenance of Navigation Channels in the Bisanseto Sea. In Coastal Engineering 1998: Proceedings of the 26th International Conference, Copenhagen, Denmark, 22-26 June 1998; ASCE: Copenhagen, Denmark, 1998; pp. 3490-3502.

13. Németh, A.A.; Hulscher, S.J.M.H.; de Vriend, H.J. Modelling sand wave migration in shallow shelf seas. Cont. Shelf Res. 2002, 22, 2795-2806. [CrossRef]

14. Besio, G.; Blondeaux, P.; Brocchini, M.; Vittori, G. On the modeling of sand wave migration. J. Geophys. Res. Ocean. 2004, 109, 1-13. [CrossRef] 
15. Van Gerwen, W.; Borsje, B.W.; Damveld, J.H.; Hulscher, S.J.M.H. Modelling the effect of suspended load transport and tidal asymmetry on the equilibrium tidal sand wave height. Coast. Eng. 2018, 136, 56-64. [CrossRef]

16. Roetert, T.; Raaijmakers, T.; Borsje, B. Cable Route Optimization for Offshore Wind Farms in Morphodynamic Areas. In Proceedings of the 29th International Ocean and Polar Engineering Conference, Honolulu, HI, USA, 16-21 June 2019; p. 12.

17. De Jong, M.F.; Borsje, B.W.; Baptist, M.J.; van der Wal, J.T.; Lindeboom, H.J.; Hoekstra, P. Ecosystem-based design rules for marine sand extraction sites. Ecol. Eng. 2016, 87, 271-280. [CrossRef]

18. Jongbloed, R.H.; van der Wal, J.T.; Lindeboom, H.J. Identifying space for offshore wind energy in the North Sea. Consequences of scenario calculations for interactions with other marine uses. Energy Policy 2014, 68, 320-333. [CrossRef]

19. van Dalfsen, J.A.A.; Essink, K. Benthic Community Response to Sand Dredging and Shoreface Nourishment in Dutch Coastal Waters. Senckenbergiana Maritima 2001, 31, 329-332. [CrossRef]

20. Van Oyen, T.; de Swart, H.; Blondeaux, P. Formation of rhythmic sorted bed forms on the continental shelf: An idealised model. J. Fluid Mech. 2011, 684, 475-508. [CrossRef]

21. Van Oyen, T.; Blondeaux, P. Grain sorting effects on the formation of tidal sand waves. J. Fluid Mech. 2009, 629, 311-342. [CrossRef]

22. Borsje, B.W.; de Vries, M.B.; Bouma, T.J.; Besio, G.; Hulscher, S.J.M.H.; Herman, P.M.J. Modeling bio-geomorphological influences for offshore sandwaves. Cont. Shelf Res. 2009, 29, 1289-1301. [CrossRef]

23. Borsje, B.W.; Kranenburg, W.M.; Roos, P.C.; Matthieu, J.; Hulscher, S.J.M.H. The role of suspended load transport in the occurrence of tidal sand waves. J. Geophys. Res. Earth Surf. 2014, 119, 701-716. [CrossRef]

24. Borsje, B.W.; Hulscher, S.J.M.H.; Herman, P.M.J.; De Vries, M.B. On the parameterization of biological influences on offshore sand wave dynamics. Ocean Dyn. 2009, 59, 659-670. [CrossRef]

25. Van Oyen, T.; de Swart, H.E.; Blondeaux, P. Bottom topography and roughness variations as triggering mechanisms to the formation of sorted bedforms. Geophys. Res. Lett. 2010, 37, 1-5. [CrossRef]

26. Van Oyen, T.; Blondeaux, P. Tidal sand wave formation: Influence of graded suspended sediment transport. J. Geophys. Res. Ocean. 2009, 114,1-18. [CrossRef]

27. Damveld, J.H.; Reijden, K.J.; Cheng, C.; Koop, L.; Haaksma, L.R.; Walsh, C.A.J.; Soetaert, K.; Borsje, B.W.; Govers, L.L.; Roos, P.C.; et al. Video transects reveal that tidal sand waves affect the spatial distribution of benthic organisms and sand ripples. Geophys. Res. Lett. 2018, 45. [CrossRef]

28. Hulscher, S.J.M.H. Tidal-induced large-scale regular bed form patterns in a three-dimensional shallow water model. J. Geophys. Res. Ocean. 1996, 101, 20727-20744. [CrossRef]

29. van der Veen, H.H.; Hulscher, S.J.M.H.; Knaapen, M.A.F. Grain size dependency in the occurrence of sand waves. Ocean Dyn. 2006, 56, 228-234. [CrossRef]

30. Van Oyen, T.; Blondeaux, P.; Van den Eynde, D. Comparing field observations of sorting patterns along tidal sand waves with theoretical predictions. Mar. River Dune Dyn. 2013, 291-296. [CrossRef]

31. Reiss, H.; Degraer, S.; Duineveld, G.C.A.; Kröncke, I.; Aldridge, J.; Craeymeersch, J.A.; Eggleton, J.D.; Hillewaert, H.; Lavaleye, M.S.S.; Moll, A.; et al. Spatial patterns of infauna, epifauna, and demersal fish communities in the North Sea. ICES J. Mar. Sci. J. Du Cons. 2010, 67, 278-293. [CrossRef]

32. Aldridge, J.N.; Parker, E.R.; Bricheno, L.M.; Green, S.L.; van der Molen, J. Assessment of the physical disturbance of the northern European Continental shelf seabed by waves and currents. Cont. Shelf Res. 2015, 108, 121-140. [CrossRef]

33. Wilson, R.J.; Speirs, D.C.; Sabatino, A.; Heath, M.R. A synthetic map of the north-west European Shelf sedimentary environment for applications in marine science. Earth Syst. Sci. Data 2018, 10, 109-130. [CrossRef]

34. Svenson, C.; Ernstsen, V.B.; Winter, C.; Bartholomä, A.; Hebbeln, D. Tide-driven Sediment Variations on a Large Compound Dune in the Jade Tidal Inlet Channel, Southeastern North Sea. J. Coast. Res. 2009, 361-365.

35. Blondeaux, P. Sediment mixtures, coastal bedforms and grain sorting phenomena: An overview of the theoretical analyses. Adv. Water Resour. 2012, 48, 113-124. [CrossRef]

36. Venditti, J.G. 9.10 Bedforms in Sand-Bedded Rivers. In Treatise on Geomorphology; Shroder, J.F., Ed.; Academic Press: San Diego, CA, USA, 2013; pp. 137-162. ISBN 978-0-08-088522-3. 
37. Lefebvre, A.; Paarlberg, A.J.; Ernstsen, V.B.; Winter, C. Flow separation and roughness lengths over large bedforms in a tidal environment: A numerical investigation. Cont. Shelf Res. 2014, 91, 57-69. [CrossRef]

38. Lefebvre, A.; Paarlberg, A.J.; Winter, C. Characterising natural bedform morphology and its influence on flow. Geo-Marine Lett. 2016, 36, 379-393. [CrossRef]

39. Best, J.; Kostaschuk, R. An experimental study of turbulent flow over a low-angle dune. J. Geophys. Res. Ocean. 2002, 107, 18-19. [CrossRef]

40. Kleinhans, M.G.; Schuurman, F.; Bakx, W.; Markies, H. Meandering channel dynamics in highly cohesive sediment on an intertidal mud flat in the Westerschelde estuary, the Netherlands. Geomorphology 2009, 105, 261-276. [CrossRef]

41. Paarlberg, A.J.; Dohmen-Janssen, C.M.; Hulscher, S.J.M.H.; Termes, P. Modeling river dune evolution using a parameterization of flow separation. J. Geophys. Res. Earth Surf. 2009, 114, 1-17. [CrossRef]

42. Janssen, F.; Bayani Cardenas, M.; Sawyer, A.; Dammrich, T.; Krietsch, J.; de Beer, D. A comparative experimental and multiphysics computational fluid dynamics study of coupled surface-subsurface flow in bed forms. Water Resour. Res. 2012, 48, 1-16. [CrossRef]

43. Damen, J.M.; Dijk, T.A.G.P.; Hulscher, S.J.M.H. Spatially Varying Environmental Properties Controlling Observed Sand Wave Morphology. J. Geophys. Res. Earth Surf. 2018, 123, 262-280. [CrossRef]

44. Terwindt, J.H.J. Sand waves in the southern bight of the North Sea. Mar. Geol. 1971, 10, 51-67. [CrossRef]

45. Van Lancker, V.R.M.; Jacobs, P. The dynamical behaviour of shallow-marine dunes. In Proceedings of the International Workshop on Marine Sandwave Dynamics, Lille, France, 23-24 March 2000; Trentesaux, A., Garlan, T., Eds.; University of Lille 1: Lille, France, 2000; pp. 213-220.

46. Stolk, A. Variation of sedimentary structures and grainsize over sandwaves. Mar. Sandwave Dyn. 2000, 1, 23-24.

47. Passchier, S.; Kleinhans, M.G. Observations of sand waves, megaripples, and hummocks in the Dutch coastal area and their relation to currents and combined flow conditions. J. Geophys. Res. Earth Surf. 2005, 110, 1-15. [CrossRef]

48. Roos, P.C.; Hulscher, S.J.M.H.; Van Der Meer, F.; Wientjes, I.G.M. Grain size sorting over offshore sandwaves: Observations and modelling. In Proceedings of the 5th IAHR Symposium on River, Coastal and Estuarine Morphodynamics, Enschede, The Netherlands, 17-21 September 2007; Dohmen-Janssen, C., Hulscher, S.J.M.H., Eds.; CRC Press: Enschede, The Netherlands, 2007; pp. 649-656.

49. Koop, L.; Amiri-Simkooei, A.; van der Reijden, K.J.; O’Flynn, S.; Snellen, M.; Simons, D.G. Seafloor Classification in a Sand Wave Environment on the Dutch Continental Shelf Using Multibeam Echosounder Backscatter Data. Geosciences 2019, 9, 142. [CrossRef]

50. Nugteren, P.; Moodley, L.; Brummer, G.-J.; Heip, C.; Herman, P.; Middelburg, J. Seafloor ecosystem functioning: The importance of organic matter priming. Mar. Biol. 2009, 156, 2277-2287. [CrossRef] [PubMed]

51. Bauer, J.E.; Cai, W.-J.; Raymond, P.A.; Bianchi, T.S.; Hopkinson, C.S.; Regnier, P.A.G. The changing carbon cycle of the coastal ocean. Nature 2013, 504, 61-70. [CrossRef] [PubMed]

52. Stephens, M.P.; Kadko, D.C.; Smith, C.R.; Latasa, M. Chlorophyll-a and pheopigments as tracers of labile organic carbon at the central equatorial Pacific seafloor. Geochim. Cosmochim. Acta 1997, 61, 4605-4619. [CrossRef]

53. Boon, A.; Duineveld, G. Chlorophyll a as a marker for bioturbation and carbon flux in southern and central North Sea sediments. Mar. Ecol. Prog. Ser. 1998, 162, 33-43. [CrossRef]

54. Bianchi, T.S. The role of terrestrially derived organic carbon in the coastal ocean: A changing paradigm and the priming effect. Proc. Natl. Acad. Sci. USA 2011, 108, 19473-19481. [CrossRef]

55. Szymczak-Żyła, M. Analysis of chloropigments in marine sediments using accelerated solvent extraction (ASE). Limnol. Oceanogr. Methods 2016, 14, 477-489. [CrossRef]

56. Ramírez-Ortega, D.B.; Soto, L.A.; Estradas-Romero, A.; Hernández-Sandoval, F.E. Photosynthetic Pigments Contained in Surface Sediments from the Hydrothermal System of Guaymas Basin, Gulf of California. J. Mar. Biol. 2019, 2019, 1-8. [CrossRef]

57. Wilson, A.M.; Huettel, M.; Klein, S. Grain size and depositional environment as predictors of permeability in coastal marine sands. Estuar. Coast. Shelf Sci. 2008, 80, 193-199. [CrossRef]

58. Jenness, M.I.; Duineveld, G.C.A. Effects of tidal currents on chlorophyll a content of sandy sediments in the southern North Sea. Mar. Ecol. Prog. Ser. Oldend. 1985, 21, 283-287. [CrossRef] 
59. Huettel, M.; Gust, G. Solute release mechanisms from confined sediment cores in stirred benthic chambers and flume flows. Mar. Ecol. Prog. Ser. 1992, 82, 187-197. [CrossRef]

60. Rusch, A.; Huettel, M. Advective particle transport into permeable sediments-evidence from experiments in an intertidal sandflat. Limnol. Oceanogr. 2000, 45, 523-533. [CrossRef]

61. Serpetti, N.; Witte, U.F.M.; Heath, M.R. Statistical Modeling of Variability in Sediment-Water Nutrient and Oxygen Fluxes. Front. Earth Sci. 2016, 4, 65. [CrossRef]

62. 4TU. Centre for Research Data. Available online: https://data.4tu.nl/repository/uuid:0d7e016d-2182-46eabc19-cdfda5c20308 (accessed on 19 May 2020).

63. Puig, P.; Canals, M.; Company, J.B.; Martín, J.; Amblas, D.; Lastras, G.; Palanques, A.; Calafat, A.M. Ploughing the deep sea floor. Nature 2012, 489, 286-289. [CrossRef]

64. R Core Team. R: A Language and Environment for Statistical Computing; R Foundation for Statistical Computing: Vienna, Austria, 2019.

65. Hijmans, R.J. Raster: Geographic Data Analysis and Modeling; R package version 2.6-7: Davis, CA, USA, 2017.

66. IHO-IOC. General Bathymetric Chart of the Oceans. Available online: https://www.gebco.net/data_and_ products/gridded_bathymetry_data/ (accessed on 8 February 2018).

67. McCave, I.N.; Bryant, R.J.; Cook, H.F.; Coughanowr, C.A. Evaluation of a laser-diffraction-size analyzer for use with natural sediments. J. Sediment. Res. 1986, 56, 561-564. [CrossRef]

68. Nieuwenhuize, J.; Maas, Y.E.M.; Middelburg, J.J. Rapid analysis of organic carbon and nitrogen in particulate materials. Mar. Chem. 1994, 45, 217-224. [CrossRef]

69. Ritchie, R.J. Consistent sets of spectrophotometric chlorophyll equations for acetone, methanol and ethanol solvents. Photosynth. Res. 2006, 89, 27-41. [CrossRef] [PubMed]

70. Glud, R.N.; Gundersen, J.K.; Revsbech, N.P.; Jorgensen, B.B.; Huettel, M. Calibration and performance of the stirred flux chamber from the benthic lander Elinor. Deep Sea Res. Part I Oceanogr. Res. Pap. 1995, 42, 1029-1042. [CrossRef]

71. Glud, R.N.; Forster, S.; Huettel, M. Influence of radial pressure gradients on solute exchange in stirred benthic chambers. Mar. Ecol. Prog. Ser. 1996, 141, 303-311. [CrossRef]

72. Lenth, R.V. Least-Squares Means: The R Package lsmeans. J. Stat. Softw. 2016, 69, 1-33. [CrossRef]

73. Van Dijk, T.A.G.P.; van Dalfsen, J.A.; van Lancker, V.; van Overmeeren, R.A.; van Heteren, S.; Doornenbal, P.J. Benthic Habitat Variations Over Tidal Ridges, North Sea, The Netherlands. Seafloor Geomorphol. Benthic Habitat 2012, 241-249. [CrossRef]

74. Knaapen, M.A.F. Sandwave migration predictor based on shape information. J. Geophys. Res. Earth Surf. 2005, 110. [CrossRef]

75. Van Dijk, T.A.G.P.; Lindenbergh, R.C.; Egberts, P.J.P. Separating bathymetric data representing multiscale rhythmic bed forms: A geostatistical and spectral method compared. J. Geophys. Res. Earth Surf. 2008, 113. [CrossRef]

76. Santos, I.R.; Eyre, B.D.; Huettel, M. The driving forces of porewater and groundwater flow in permeable coastal sediments: A review. Estuar. Coast. Shelf Sci. 2012, 98, 1-15. [CrossRef]

77. Hedges, J.I.; Keil, R.G. Sedimentary organic matter preservation: An assessment and speculative synthesis. Mar. Chem. 1995, 49, 81-115. [CrossRef]

78. Burdige, D.J. Preservation of Organic Matter in Marine Sediments: Controls, Mechanisms, and an Imbalance in Sediment Organic Carbon Budgets? Chem. Rev. 2007, 107, 467-485. [CrossRef]

79. Serrano, O.; Lavery, P.; Duarte, C.; Kendrick, G.; Calafat, A.; York, P.; Steven, A.; Macreadie, P. Can mud (silt and clay) concentration be used to predict soil organic carbon content within seagrass ecosystems? Biogeosciences 2016, 13, 4915-4926. [CrossRef]

80. Dalrymple, R.W. Morphology and internal structure of sandwaves in the Bay of Fundy. Sedimentology 1984, 31, 365-382. [CrossRef]

81. Kröncke, I.; Reiss, H.; Dippner, J.W. Effects of cold winters and regime shifts on macrofauna communities in shallow coastal regions. Estuar. Coast. Shelf Sci. 2013, 119, 79-90. [CrossRef]

82. Franco, M.; Vanaverbeke, J.; Oevelen, D.; Soetaert, K.; Costa, M.; Vincx, M.; Moens, T. Respiration partitioning in contrasting subtidal sediments: Seasonality and response to a spring phytoplankton deposition. Mar. Ecol. 2010, 31, 276-290. [CrossRef] 
83. Rumyantseva, A.; Henson, S.; Martin, A.; Thompson, A.F.; Damerell, G.M.; Kaiser, J.; Heywood, K.J. Phytoplankton spring bloom initiation: The impact of atmospheric forcing and light in the temperate North Atlantic Ocean. Prog. Oceanogr. 2019, 178, 102202. [CrossRef]

84. Gabas, N.; Hiquily, N.; Laguérie, C. Response of Laser Diffraction Particle Sizer to Anisometric Particles. Part. Part. Syst. Charact. 1994, 11, 121-126. [CrossRef]

85. Kaye, B.H.; Alliet, D.; Switzer, L.; Turbitt-Daoust, C. The Effect of Shape on Intermethod Correlation of Techniques for Characterizing the Size Distribution of Powder. Part 1: Correlating the Size Distribution Measured by Sieving, Image Analysis, and Diffractometer Methods. Part. Part. Syst. Charact. 1997, 14, 219-224. [CrossRef]

86. Neumann, A.; Möbius, J.; Hass, H.C.; Puls, W.; Friedrich, J. Empirical model to estimate permeability of surface sediments in the German Bight (North Sea). J. Sea Res. 2016, 127, 36-45. [CrossRef]

87. Mietta, F.; Chassagne, C.; Manning, A.J.; Winterwerp, J.C. Influence of shear rate, organic matter content, $\mathrm{pH}$ and salinity on mud flocculation. Ocean Dyn. 2009, 59, 751-763. [CrossRef]

88. Gerbersdorf, S.U.; Bittner, R.; Lubarsky, H.; Manz, W.; Paterson, D.M. Microbial assemblages as ecosystem engineers of sediment stability. J. Soils Sediments 2009, 9, 640-652. [CrossRef]

89. Decho, A.W.; Gutierrez, T. Microbial Extracellular Polymeric Substances (EPSs) in Ocean Systems. Front. Microbiol. 2017, 8, 922. [CrossRef] [PubMed]

90. Eshel, G.; Levy, G.; Mingelgrin, U.; Singer, M. Critical Evaluation of the Use of Laser Diffraction for Particle-Size Distribution Analysis. Reprod. Soil Sci. Soc. Am. J. Publ. Soil Sci. Soc. Am. All Copyr. Reserv. 2004, 68. [CrossRef]

91. Blott, S.J.; Pye, K. Particle size distribution analysis of sand-sized particles by laser diffraction: An experimental investigation of instrument sensitivity and the effects of particle shape. Sedimentology 2006, 53, 671-685. [CrossRef]

(C) 2020 by the authors. Licensee MDPI, Basel, Switzerland. This article is an open access article distributed under the terms and conditions of the Creative Commons Attribution (CC BY) license (http://creativecommons.org/licenses/by/4.0/). 